\title{
CONTROL OF PATENTED AND COPYRIGHTED ARTICLES AFTER SALE
}

The provision of the Federal Constitution under which Congress acts in enacting patent or copyright laws is expressed in very general terms:

"To promote the progress of science and useful arts, by securing for limited terms to authors and inventors the exclusive right to their respective writings and discoveries."

What is meant by an "exclusive right"? How far does this control extend? 'Can it continue after absolute sale of the patented or copyrighted article? What is, here, the effect of that principle of the common law that one cannot part with the fee of chattels and at the same time annex conditions to their use? Is the right of patent or copyright of such a nature that it protects one to whom it is granted from the operation of statutes against restraint of trade or unfair competition? Is there a difference between the rights granted by patent laws and those granted by copyright laws? These and similar questions have been often before the courts in recent years; but the difficulty of reconciling a body of law unknown to the common law ${ }^{2}$ with the principles of that common law, and likewise of reconciling rights that are essentially monopolies with enactments like the Sherman Law ${ }^{3}$ and the more recent Clayton Law, ${ }^{4}$ means that many decisions are yet necessary before we can speak authoritatively on all important phases of our patent and copyright laws.

We will first consider our subject with reference to patents, although much that is said of patents is equally applicable to copyrights. However, when the Supreme Court quotes with approval a statement that there are such wide differences between patents and copyrights that the cases which relate to the one subject are not altogether controlling as to the other, ${ }^{5}$ it is perhaps best not to think of them as too closely connected, and

1 Art. I, sec. 8.

2 Gayler v. Wilder (1850) Io How. (U. S.) $477,493$.

3 (1890) 26 St. at L. 209.

4 (I9I4) 38 St. at L. 730.

5 Park \& Sons So. v. Hartman (1907) 153 Fed. 24, 28, quoted in BobbsMerrill Co.v. Straus (1908) 201 U. S. 339, 345. 
to cite with considerable caution a patent case in a copyright matter, and vice versa.

While the Constitution indicates that patentees are to be protected, the specific privileges to be accorded them are only such as Congress may allow, ${ }^{6}$ and the statutory provision applicable to patents as found in the Revised Statutes, the exact wording of which it is well to keep in mind in discussing the limitations of any patent monopoly, is as follows:

"Every patent shall contain . . . . . a grant to the patentee, his heirs or assigns, for the term of seventeen years, of the exclusive right to make, use and vend the invention or discovery. . . . . . ."

The restrictions which a patentee desires to impose has one or both of two objects-he wishes either, (I) to limit the use of the article in some particular manner, or, (2) to prevent its sale below a certain price, usually fixed by himself. His method of seeking to accomplish his object may be either, (I) by contracts with vendees and subvendees, or, (2) by notices affixed to the patented article by which he intends to bind anyone into whose hands the same may come.

\section{RESTRICTIONS ON THE USE OF A PATENTED ARTICLE}

Lord Coke made a comment that very frequently appears in brief or opinion in cases involving patent restrictions because it is presumed to indicate a difficult problem in supporting a restriction on use or price after sale:

"If a man be possessed of a horse or any other chattel, real or personal, and give his whole interest or property therein, upon condition that the donee or vendee shall not alien the same, the same is void, because his whole interest is out of him, so as he hath no possibility of reverter; and it is against trade and traffic and bargaining and contracting between man and man."

Now the difficulty with a patent is that the patentee seems to part with his entire interest and yet in many respects dictates, as we shall see, what his vendee may do with the patented article.

${ }^{6}$ Banks v. Manchester (1888) I28 U. S. 244.

7 Rev. St. sec. 4884.

${ }^{8}$ Coke, Litt. sec. 360. 
But this difficulty is more apparent than real, for it arises from a failure to distinguish between the property right in the materials composing a patented article, and the right of use for the purpose and manner pointed out by the patent. ${ }^{\circ}$ That distinction is mentioned at the outset because so much loose thinking has resulted from failure to apprehend it. The patent laws do not give the patentee the right to sell or use his patented article-he has these rights without a patent-but they do give him an incorporeal right, a right to exclude others from using his invention or discovery, ${ }^{10}$ and that right-entirely distinct from the right of property in the materials-is often of much greater value than the materials of which the article is made.

But is should be noted that the patentee himself must separate ownership and use, and evidence his intention so to do very clearly, or he will find that he has no further control of his product. Thus, there is a general rule that the unconditional or unrestricted sale of a patented article conveys the entire use. Even here, however, the distinction between the right of ownership and the right of use has not been lost sight of ; for as Mr. Justice Lurton points out, "this right to use is nothing more nor less than an unrestricted license presumed from an unconditional sale," and the license itself passes no interest in the monopoly. He sums up the distinction, with his usual clearness, in one succinct paragraph:

"We repeat. The property right to a patented machine may pass to a purchaser with no right of use, or with only the right to use in a specified way, or at a specified place, or for a specified purpose. The unlimited right of exclusive use which is possessed by and guaranteed to the patentee will be granted if the sale be unconditional. But if the right of use be confined by specific reservation, the use not permitted is necessarily reserved to the patentee. If that reserved control of use of the machine be violated, the patent is thereby invaded. The right to sever ownership and use is deducible from the nature of a patent monopoly and is recognizable in the cases."11

Turning now to the cases suggested by our subhead, the decision of Circuit Judge Lurton in the so-called Button Fastener

${ }^{2}$ Henry v. Dick Co. (1912) 224 U. S. I, 24.

${ }^{10}$ Jewett v. Atwood Suspender Co. (1900) roo Fed. 647, 648.

${ }^{11}$ Henry v. Dick Co. (19r2) 224 U. S. I, 24. 
case $^{12}$ has been characterized by Chief Justice White, who disagrees with it, as "the leading one of the cases which all the others but follow." 13

The owner of a patented machine for fastening buttons to shoes with metallic fasteners sold the machine with a metal label affixed thereto containing a statement, entitled, "Condition of sale," as follows:

"This machine is sold and purchased to use only with the fasteners made by the Peninsular Novelty Co., to whom the title to said machine immediately reverts upon violation of this contract of sale."

It was held that the label, conspicuously affixed, bound both jobbers and their vendees, even though the patent owner did not deal directly with users. But the court went further, and enjoined the sale to the users of such machines of staples not made by the complainant, but by a manufacturer of staples who intended his staples to be used in complainant's machines.

Substantially similar facts brought the questions involved before the Supreme Court in Henry v. A. B. Dick Co. ${ }^{14}$ The opinion in this case was also delivered by Mr. Justice Lurton. A. B. Dick Company owned a patent covering a stencil duplicating machine known as the "rotary mimeograph." It sold to one Skou such a mimeograph, with a "license restriction" attached to the machine as follows:

"This machine is sold by the A. B. Dick Company with the license restriction that it may be used only with the stencil, paper, ink and other supplies, made by A. B. Dick Company, Chicago, U. S. A."

It is stated that the Dick Company sold its machine at cost or less, depending upon the profit realized from the sale of the non-patented articles to be used with the machine for the gain to be received from its invention. Henry sold to Skou a can of ink suitable for use upon the said mimeograph, with knowledge of the said license agreement, and with the expectation that it would be used in connection with the said mimeograph. The ink sold to Skou was not covered by the claims of the patent.

12 (1896) 77 Fed. 288.

13 Hetry v. Dick Co. (1912) 224 U. S. I, 68.

14 (I9I2) 224 U. S. I. 
It was held that this act of Henry's constituted contributory infringement of complainant's patent. ${ }^{15}$

It should be noted how far these cases go. In each, the suit is not against one having any contractual relation or privity with the patentee but against a maker of an unpatented article in ordinary use. The patentee admittedly has no exclusive right to the manufacture of this unpatented article and his only control over its use arises out of his patent on his machine. The notice which binds the licensee, or the third party, need not rest in contract, but is sufficiently brought home by attaching the label containing the same to the machine.

Few recent decisions have attracted as much attention as the Dick case, and the fact that it was actually decided by a minority of the full membership of the court will probably bring the question once more before our highest tribunal. In fact, the decision in Bauer \& Cie v. O'Donnell, ${ }^{16}$ which we shall comment on later in this article, has already much shaken it.

The dissent of the Chief Justice is interesting as showing what would be the probable basis of a contrary ruling, were the court ever to reverse itself. His chief objection is that the doctrine laid down by the majority places in the hands of the patentee a "virtual legislative authority" over every person, without reference to privity of contract between patentee and his vendee. ${ }^{17}$ He puts various illustrations of the extremes to which this doctrine may lead-a patentee selling a patent engine may now bring under the patent laws ail contracts for coal or electrical energy needed to work the machine, a patentee of a carpenter's plane may by contract prescribe that the same may only be used on lumber from trees grown on the land of a particular person or sawed by a particular mill, and so on. ${ }^{18}$

Furthermore, he says, this decision loses sight of a distinction made many years ago by this court-the difference between the rights of a patentee protected by a patent, and the rights of a patentee which merely arise from contract, and therefore are

${ }^{15}$ Four judges, Lurton, McKenna, Holmes and Van Devanter, JJ., formed the majority, and three, White, C. J., Hughes and Lamar, JJ., dissented. A petition for a rehearing, in which the Attorney General and Solicitor General joined, was denied.

${ }^{16}$ (I9I3) 229 U. S. I.

${ }^{17}$ Henry v. Dick Co. (1912) 224 U. S. I, 54.

${ }^{18}$ Henry v. Dick Co. (I9I2) 224 U. S. I, 55. 
subject only to the general law of the particular jurisdiction. ${ }^{19}$ This, said the Chief Justice, was a sale of all the rights which the patent protected (in spite of the so-called license restriction. And the decision also fails to note the distinction between the grant of the right to make and vend a patented machine, and the grant of the right to use it. When the patentee, for example, sells the exclusive privilege of making or vending the machine for use in a particular place, the purchaser buys a portion of the franchise which the patent confers but the purchaser of the machine who intends to use it in the ordinary pursuits of life stands on different ground; for in using it he does not derive title to it by virtue of the franchise or exclusive privilege granted by act of Congress, but by reason of the laws of property of the particular state in which it is located. ${ }^{20}$

It seems possible to answer these objections. There is an obvious remedy to the danger of great public inconvenience suggested by the Chief Justice in that, as Justice Lurton points out, ${ }^{21}$ the public is always free to take or refuse the patented article on the terms imposed by the patentee. If he chooses to place onerous burdens on users, he will speedily find himself without a market. To the contention that many patented articles are almost necessaries and the public will suffer if their use is unduly burdened it may be said that it is the undoubted policy of our patent laws to give the patentee practically absolute power during the life of his patent for the sake of the compensation that will come to the public when it shall be open to unrestricted use. He may be as capricious as he wishes-he may refuse to use it himself and at the same time prevent others from doing so. ${ }^{22}$ He has "a constitutional and statutory monopoly" ${ }^{23}$ and he can say, in the language of Holy Writ, to anyone who makes objection, "Is it not lawful for me to do what I will with mine own?"

And when we come to examine the cases cited by the Chief Justice, we find that those on which he places greatest reliance are cases of unconditional sales, where the general rule that we

${ }^{19}$ Henry v. Dick Co. (1912) 224 U. S. I, 56 ff., citing Wilson v. Sanford (I850) 1o How. (U. S.) 99.

${ }^{20}$ Citing Bloomer v. $M c Q$ uewan (I852) I4 How. (U. S.) 539.

21 Henry v. Dick Co. (I9I2) 224 U. S. I, 34.

22 Paper Bag Patent Case (1908) 210 U. S. 405.

${ }^{23}$ Henry v. Dick Co. (I912) 224 U. S. I, 35. 
have mentioned applies, namely, the sale conveys the entire use. It is difficult to see how a suit for infringement, which must turn upon the scope of the monopoly or privilege secured to a patentee, does not present a case arising under the patent laws. This is not a claim for damages for breach of contract, nor for payment of royalties, but a claim which, construed one way, gives rights under the patent laws and, construed another, defeats those rights. ${ }^{24}$

On the whole, the decision in Henry v. Dick Co. seems right. When we turn to the language of the patent statute-"to make, use and vend"- we can well say, as a matter of construction, that things necessary to the use of the patented article come within the purview of the statute. The monopoly in the unpatented article used with the patented machine is strictly incidental to the use of the machine, concerns nothing but its actual use and arises from the peculiar merits of the machine-the very thing the patent laws are intended to cover. When some one else shall invent a more ingenious machine, then this machine will be superseded and with it will go any monopoly the patentee might have in the unpatented article. ${ }^{25}$

Nor does the decision appear to be as broad as the minority opinion would make it. It would seem to be confined to articles actually necessary to the use of the pattented article-ink for the rollers, stencils for mimeographing, etc.-and not necessarily to embrace the completed products that come from the machine or materials on which the machine is to do some work. The decision does not read that only cloth manufactured by a certain mill shall be used on a patented sewing-machine, or only pencils made by a certain manufacturer shall be sharpened in a patented pencilsharpener. This is a close distinction-so close, at times, that it is difficult to tell where daylight ends and dark begins. ${ }^{26}$ However, it is submitted that the distinction is a sound one when the court specifically confines its decision to "things necessary to the use of the patented article."

24 Henry v. Dick Co. (1912) 224 U. S. I, 16.

${ }^{25}$ Button Fastener case (1896) 77 Fed. 288, 296.

${ }^{26}$ For example, in the Dick case (I9I2) 224 U. S. I, the license covered paper-a material necessary to operate the machine and not the completed product coming from it.

27 Henry v. Dick Co. (1912) 224 U. S. 1, 36. The English authorities are in accord with the Dick case, pp. 39-43. 
RESTRICTIONS ON THE PRICE OF A PATENTED ARTICLE

Is any difference to be made between a restriction on use and a restriction on price?

The Revised Statutes give the patentee three exclusive rights: to make, to use, to vend, and these rights are several so that one may be given without the other two. ${ }^{28}$ It therefore becomes necessary to interpret the meaning to be attached to each of the three words, and we are here, of course, concerned with the connotation to be given the word, "vend." Does the exclusive right to "vend" carry with it the power by notice to limit the price at which future retail sales of the patented article may be made?

The Supreme Court has answered that question in the fairly recent case of Bauer \& Cie v. O'Donnell. ${ }^{29}$ The defendant, a retail druggist, purchased from jobbers who had purchased from plaintiff at the full price demanded by plaintiff, original packages of a patented medicine known as "Sanatogen." On these packages was a "Notice to the Retailer" which read that the package was licensed for sale and use at a price not less than one dollar; that any sale at a less price was an infringement of the patent; that a purchase was an acceptance of this condition and all rights reverted to the patentee in the event of violation. Defendant sold packages at less than one dollar and the Court of Appeals of the District of Columbia certified the following question to the Supreme Court:

"Did the acts of the appellee, in retailing at less than the price fixed in said notice, original packages of 'Sanatogen' purchased of jobbers as aforesaid, constitute infringement of the appellants' patent?"30

The Supreme Court answered the question in the negative. ${ }^{31}$ The opinion was written by Mr. Justice Day, who had taken no part in the decision of the Dick case, and the four justices who comprised the majority in that case here dissented without opinion.

It is submitted the Sanatogen case and the Dick case cannot both be upheld, although the court professes to distinguish the latter. The court in the Sanatogen case uses this language:

\footnotetext{
${ }^{28}$ Henry v. Dick Co. (1912) 224 U. S. I, 46.

29 (I9r3) 229 U. S. I.

30 Baner \& Cie v. O'Donnell (IgI3) 229 U. S. I, 9.

31 Accord, Victor Talking Machine Co. v. Straus (1915) 222 Fed. 524.
} 
"The patentee had no interest in the proceeds of the subsequent sales, no right to any royalty thereon or to participation in the profits thereof. The packages were sold with as full and complete title as any article could have when sold in the open market, excepting only the attempt to limit the sale or use when sold for not less than one dollar. In other words, the title transferred was full and complete with an attempt to reserve the right to fix the price at which subsequent sales could be made. There is no showing of a qualified sale for less than value for limited use with other articles only, as was shown in the Dick case. There was no transfer of a limited right to use this invention, and to call the sale a license to use is a mere play upon words. ${ }^{32}$

It is not a license to use, certainly, but here we are concerned with the right to vend. Justice Day says the right to vend conferred by the patent law has been exercised when the package was sold with a full and complete title as any article could have been in the open market. But what was the exclusive right to vend given by the patent laws? Was it merely to sell the article? The patent law did not give that right, for the patentee always had it, irrespective of any patent. And does it matter that the materials composing the package were sold with an absolutely full and complete title? A property right in the mere goods is entirely separate and distinct from an interest in the monopoly. Mr. Justice Lurton made that clear in the Dick case. It is true that there he was talking about the distinction between the property right in the goods and the right to control use, but is there not a similar distinction between the property right in the goods and the right to vend? If the word, "vend," is to have any particular meaning in the patent law, it is submitted it must be taken to refer to the conditions which may be imposed on subsales. The meaning given it in the Sanatogen case is nothing more than a mere truism-that a man may sell his own property. Test the court's interpretation of "vend" by inquiring what rights this interpretation gives the patentee that he would not have if it were struck out of the law. If the patent law merely referred to "the exclusive right to make and use," no one else could sell because no one else could make.

The court says that here (unlike the Button Fastener or Dick cases) there was no showing of a qualified sale for less than

32 (1913) 229 U. S. I, 16. 
value for limited use with other articles only. This remark seems to indicate that in the court's mind it is of some importance whether or not the patentee sells the article at its real worth. If that is a correct interpretation, aside from the diffcult problem of proving whether an article is sold at or below cost, it would be interesting to inquire how that fact has any bearing on the question of what rights are protected by a patent. If the patentees of Sanatogen had received the full purchase price which satisfied them, whether that price was one dollar or one cent, the purchaser would have that "full and complete title" on which the count based its decision.

On three grounds, at least, it is submitted the decision in Bauer \& Cie v. O'Donnell should not be supported:

(I) It ignores the fundamental distinction between the right of property in the patented article and the monopoly given by the patent law.

(2) It interprets "the exclusive right to vend" given by the patent law in a manner that makes that phrase devoid of meaning.

(3) It opens an opportunity for much useless discussion of the value and sale price of patented articles. ${ }^{33}$

\section{RESTRICTIONS ON THE PRICE OF A COPYRIGHTED ARTICLE}

The language of the copyright law is as follows:

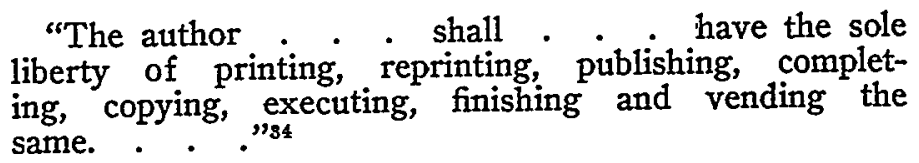

The leading case on the right to restrict the price of a copyrighted article, is Bobbs-Merrill Co. v. Straus et al., ${ }^{35}$ in which Mr. Justice Day delivered the opinion of the court. The defendants were sued by the plaintiff to restrain the sale of a copyrighted novel, entitled, The Castaway, at a price less than

83 For cases contra, see Bement v. National Harrow Co. (1902) 186 U. S. 70, 9I, and the cases cited in Park \& Sons Co. v. Hartman (1907) I53 Fed. 24, 27.

34 Rev. St. $4952 ; 33$ St. at L. 1000.

35 (1908) 210 U. S. 339. The defendants were R. H. Macy \& Co., a New York department store which has done much to settle the law on the subjects we are discussing. 
one dollar. Immediately below the copyright notice on the page following the title page was the following notice:

"The price of this book at retail is one dollar net; no dealer is licensed to sell it at a less price, and a sale at a less price will be treated as an infringement of the copyright."

The defendants purchased most of their supply from wholesale dealers at a price below the retail price by about forty per cent, and it was conceded that both the wholesale dealers and defendants knew of the notice, but the former were under no agreement to enforce the same.

The decision was that the owner of the copyright could not, in the absence of contract or license, restrict future sales of the book at retail to the right to sell it at a certain price per copy, even though the notice was brought home to one undertaking to sell for less than the named sum.

At this time the court was under the necessity of holding the patent cases to be no precedent, for the decision in the Bement case $^{36}$ and many cases in the lower courts, were contrary, but it is interesting to note that as soon as this necessity disappeared, the same court and the same judge thought that,

"the right to vend secured in the patent statute is not distinguishable from the right of vending given in the copyright aot. In both instances it was the intention of Congress to secure an exclusive right to sell, and there is no grant of a privilege to keep up prices and prevent competition by notices restricting the price at which the article may be resold. ${ }^{\prime 37}$

Thus, to-day, the price of neither a patented nor a copyrighted article may be fixed by the patentee or copyright owner, merely by a notice attached to the article.

It will be noted that aside from the Bement case, the cases, both patent and copyright, which we have been considering deal with questions of restriction by license notice. There have been no recent contract cases before the Supreme Court.

If the use of a patented article may be restricted by mere license notice, as in the Dick case, then a fortiori it may be restricted by actual agreement, as in the Bement case. But if

${ }^{36}$ (1902) I86 U. S. 70.

${ }^{37}$ Bauer \& Cie v. O'Donnell (19I3) 229 U. S. I, I7. 
the price of a patented or copyrighted article may not be fixed by mere license notice (as the law now stands), may the same be done by contract?

Prior to the decisions in the Bobbs-Merrill case and the Bauer case, there was no doubt of the right to fix price by contract. This had been decided in numerous cases in the lower Federal courts of which perhaps the leading one was Victor Talking Machine Co. v. The Fair, ${ }^{38}$ but these cases have raised some question in the lower courts as to just what emphasis the Supreme Court intended to place on the license-notice feature. The most satisfactory discussion of this question, so far, is found in the case of American Graphophone Co. v. Boston Store. ${ }^{30}$

This case concludes that the Bauer case was not intended to cover price restriction by contract. The Bauer case dealt with a situation where no part of the patent monopoly had been reserved (since it was held that a mere notice was not sufficient to reserve it) but there was no dictum that no part of the patent monopoly could be reserved if there was an express agreement as to price, and, as the language of the Bauer case was limited to the precise facts, we are still justified in holding that an agent or vendee of a patentee may, by direct covenant or agreement, bind himself to the observance of a price restriction.

This is sound reasoning, as the Bobbs-Merrill and Bauer cases dealt with the method by which the patentee sought to restrict the price, not the lawfulness of price fixing, in general. The latter question is concerned primarily with how far price restrictions on patented or copyrighted articles are affected by antitrust and anti-monopoly legislation-the most interesting phase of our subject, to which we now come.

EFFECT OF ANTI-TRUŚT LEGISLATION ON PATENTS AND COPYRIGHTS

Patents and copyrights, as we have seen, are essentially monopolies. It is the deliberate policy of the law, based on the Constitution itself, to make them such by a grant of exclusive rights and privileges. We also have seen that even though the patentee or copyright owner should capriciously refuse to allow anyone, even himself, to have the benefit of his invention,

38 (1903) 123 Fed. 424.

39 (1915) 225 Fed. 785. 
his discovery, his book, he has that right. Mere characterization, therefore, of a patent or copyright as a monopoly does not even raise a presumption against its legality.

"Cries of restraint of trade and impairment of the freedom of sales are unavailing, because for the promotion of the useful arts the constitution and statutes authorize the very monopoly." 40

But, on the other hand, patents and copyrights are but a species of property and subject, as is all other property, to the law of the land. ${ }^{41}$ There are limitations on the rights of the patentee and the copyright owner to deal with his own. Some of these limitations are easy enough to discover. For example, a patented device for gambling is not immune from state attack ${ }^{42}$ and a burning oil which a state declares to be unsafe cannot be sold because it happens to be patented. ${ }^{43}$ In general, we may say that the rules of public policy and the police power apply to patents and copyrights equally with all other property.

But when the patent or copyright monopoly is attacked on the ground that it violates those rules against monopolies and restraint of trade which Congress itself has established, we have questions of inherent difficulty. How far must the monopoly granted by one statute be restrained and limited by the provision against monopolies in another statute or, paraphrasing Judge Lurton, ${ }^{44}$ when can we say that a monopoly created by law can be taken away by law?

There is a frank recognition of the fact that the patent and copyright laws often act as shields to monopolies which, lacking that protection, cannot be upheld under the Sherman law. This was brought out very clearly in two decisions, in one of which Circuit Judge Lurton delivered the opinion of a circuit court of appeals, ${ }^{45}$ and in the other, Mr. Justice Hughes spoke for the Supreme 'Court.to

40 Victor Talking Machine Co. v. The Fair (1903) 123 Fed. 423; and see The Great A. \& P. Tea Co. v. Cream of Wheat Co. (Igr5) 224 Fed. $566,572$.

41 Button Fastener case (1896) 77 Fed. 288, 293.

42 Vannini v. Paine (1832) I Harr. (Del.) 65.

${ }^{43}$ Patterson v. Kentucky (1878) 97 U. S. 501.

44 Park \& Sons Co. v. Hartman (rg07) I53 Fed. 24, 32.

15 Park \& Sons Co. v. Hartman (1907) 153 Fed. 24.

${ }^{16}$ Dr. Miles Medical Co. v. Park \& Sons Co. (I9II) 220 U. S. 373. 
In each of these cases the owner of a secret process or formula for manufacturing a proprietary medicine attempted by a system of contracts to control the price at which all sales by dealers at wholesale or retail should be made. In neither case, however, was the medicine patented. Defendants were alleged to have refused to make such contracts with plaintiffs as other wholesale dealers and jobbers had made, and to have induced such wholesale dealers and jobbers to break their agreements with plaintiffs, by selling to defendants below the prices set by plaintiffs.

It was held in each case that plaintiffs' attempts to control prices on all sales of their products was in restraint of trade and violative of the Sherman Act. To plaintiffs' contention that there was an analogy between the owner of a patent and the owner of a secret medical process, the Supreme Court answered that in the one case there is a statutory grant, in the other there is none, and the maker of a proprietary medicine, unpatented, stands on no different footing from that of any other manufacturer. ${ }^{47}$ The patent and copyright laws give a privilege because the public will ultimately benefit from such grant, but the owner of a secret process or formula gives nothing, and is not bound ever to reveal his process, and hence, there should be no policy of the law protecting him in any particular manner. ${ }^{48}$

This brings us to a consideration of the cases where the question of monopoly has arisen in patent and copyright cases proper.

In the case of Bement v. National Harrow Co., the earliest of the cases we are considering, the question was raised; but the court was clearly of the opinion that, even under the then prevailing doctrine that the Sherman Act forbade any restraint of commerce, reasonable or unreasonable, the Act was not applicable to the facts of that case.

"But that statute clearly does not refer to that kind of restraint of interstate commerce which may arise from reasonable and legal conditions imposed upon the assignee or licensee of a patent by the owner thereof, restricting the terms upon which the article may be used and the price to be demanded therefor. Such a construction of the act we have no doubt was never contemplated by its framers." 49

${ }^{47}$ Dr. Miles Medical Co. v. Park \& Sons Co. (I9II) 220 U. S. 373, $402 \mathrm{ff}$. 48 Park \& Sons Co. v. Hartman (1907) I53 Fed. 24, 32.

40 (1902) I86 U. S. 70, 92. 
In Pope Mfg. Co. v. Gormully, ${ }^{\text {so }}$ decided shortly after the Sherman Act went into effect, the question of patent monopoly could have been raised, but it does not seem to have been touched upon. In that case the court refused to compel specific performance of a contract wherein the defendant, in consideration of receiving a license to use certain patents, agreed never to dispute the validity of the same, nor plaintiff's title thereto, and never to import, manufacture, or sell any machines or devices covered by certain other patents not owned by plaintiffs. The decision, however, was put on the broad ground of public policy.

The case that finally brought the point squarely before the Supreme Court was Standard Sanitary $M f g$. Co. v. U. S.,51 familiarly known as the Bath Tub Trust case. Here, sixteen corporate and thirty-four individual defendants, manufacturers of enameled ware, agreed not to sell their products to jobbers except at a price fixed by a committee of six of their number. The jobbers were brought into the agreement, and unless they made the desired agreement could obtain no enameled ware from any manufacturer in the combination (which embraced eighty-five per cent of the entire trade). One condition was not to resell to plumbers except at the prices determined by the manufacturers. A defense set up to the Government's suit against a combination so obviously in violation of the Sherman Act was that this agreement was a means employed by the defendants of protecting several patents in their control, and that the form: of the license followed the precedents which gave the owner of an invention the power to grant to others its use, or to withhold it, or to grant it upon such terms as he may choose to impose. The court, however, likened the case to a similar combination already condemned, where no patents were involved, ${ }^{52}$ and then stated:

"The added element of the patent in the case at bar cannot confer immunity from a like condemnation, for the reasons we have stated ......... Rights conferred by patents are indeed very definite and extensive, but they do not give any more than other rights an universal license against positive prohibitions. The Sherman law is a limitation of rights, rights which may be pushed to evil consequences and therefore restrained." ${ }^{.93}$

\footnotetext{
50 (I892) I44 U. S. 224.

51 (1912) 226 U. S. 20.

52 Montague \& Co. v. Lozery (1904) 193 U. S. 38.

${ }^{53}$ Standard Mfg. Co. v. U. S. (I9I2) 226 U. S. 20, 49.
} 
Turning to copyrights, we find a similar decision in the case of Straus v. American Publisher's Association et al. ${ }^{54}$ The plaintiffs (R. H. Macy \& Co.) asked for an injunction restraining any interference with their purchase and sale of copyrighted books. Because the plaintiffs refused to maintain the retail prices set by them, the defendants, the publishers' association composed of seventy-five per cent of the publishers of copyrighted and uncopyrighted books in the United States, and the booksellers' association which included a majority of the booksellers throughout the United States, issued "cut-off lists," directing the discontinuance of the sale of copyrighted books to the plaintiffs, and issued circulars to the trade at large, warning all persons against dealing with the plaintiffs or other pricecutters. The Court of Appeals of New York held that so far as uncopyrighted books were concerned, the agreement was illegal and granted an injunction and damages; but that, as to copyrighted books, the agreement was justified by the copyright act, and was not within the denunciation of the Sherman Act.55 The Supreme Court reversed that judgment and held the combination illegal in either aspect. First quoting the extract given above from the Bath Tub Trust case, it proceeded:

"So, in the present case it cannot be successfully contended that the monopoly of a copyright is in this respect any more extensive than that secured under the patent law. No more than the patent statute was the copyright act intended to authorize agreements in unlawful restraint of trade and tending to monopoly, in violation of the specific terms of the Sherman Law, which is broadly designed to reach all combinations in unlawful restraint of 'trade and tending because of the agreements or combinations entered into to build up and perpetuate monopolies." ${ }^{5 B}$

We have perhaps cited enough of these cases to make some generalizations on the theory seeming to run through them all. It is worthy of note that the cases in which the court has declined to protect the monopoly granted by the patent or copyright statutes, by holding a restriction on resale price illegal or unenforceable, fall into one of two classes:

54 (Igr3) 23 I U. S. 222.

55 Straus v. American Publisher's Association et al. (1910) I99 N. Y. 548.

${ }_{56}$ Straus v. American Publisher's Association et al. (Igr3) 23 I U. S. 222, 234 . 
(I) The merchandise in question has been of such a character that the original vendor produced or marketed all of the same or similar merchandise. There could be no substitution except by the use of goods entirely different, so far as the purchaser could ascertain. Thus in the Bauer case, there was a patented medicine, "Sanatogen," made under a secret process, in the Bobbs-Merrill case there was a copyrighted book, and in Park \& Sons Co. v. Hartman and the Dr. Miles Medical Co. cases, there were unpatented proprietary medicines, secretly compounded. That there would be an actual monopoly, even though there is a patent or copyright, is obviously of weight in the court's mind and a fortiori when no patent or copyright is involved. Thus in the Peruna case Judge Lurton says:

"It is true that the complainant is not in combination with other makers of Peruna. There are no others. If there were there would not be a complete or general restraint; for it might then happen that those others, not being bound by any covenants, could supply the public..'57

(2) The restrictions (in the language of the Standard Sanitary Mfg. Co. case) "transcend what was necessary to protect the use of the patent or the monopoly which the law conferred upon it," ${ }^{28}$ and the same is true of the copyright cases.

Thus, in the case just cited, the restrictions were not reasonable and legal conditions attached to the use of the patented invention, so they restrained trade and promoted monopolization of commerce in articles not patented. The restrictions had nothing whatever to do with the use of the patented tool, but applied to acts subsequent to its use. Compare the Dick case in which the restriction named, prevented the use of paper which had not been supplied by the patentee but was a restriction only effective at the time of the use of the patented article. There was no attempt to control the output of the mimeograph nor to fix the price at which the users of the mimeograph should sell the mimeographed copies. After the Dick decision, persons were as free to manufacture paper, stencils and inks as before. The Dick company had no control over either the source of supply or the demand for those unpatented articles, and the

${ }^{57}$ Parks \& Sons Co. v. Hartman (1907) r53 Fed. 24.

58 (I912) 226 U. S. $20,48$. 
market was only curtailed as to the person who bought the patented mimeograph. On the other hand, the combination in the Sanitary case intended to control and did control every phase of the combination in enameled wares; for unless the jobbers entered the combination they could obtain no enameled ware from the manufacturers of eighty-five per cent of the product. ${ }^{39}$ And similarly in the American Publisher's case, the effect of defendants' "cut-off lists" was not merely to prevent the plaintiffs getting copyrighted books but "books of any kind at any price," except through a very small source of supply, and so, as the court says, the agreement "manifestly went beyond any fair and legal agreement to protect prices and trade."

Recent cases not involving patents or copyrights have upheld price-fixing, and, just as the cases that have denounced it, have laid emphasis on the fact of monopoly, so these cases have stressed the non-monopolistic features of the price-fixer's business. Thus, in Fisher Flouring Mills v. Swanson, the court said:

"Such a contract as that here in question is of interest to the public only when the whole of the given commodity, or a measurable approximation to the whole of that given commodity, is in the control of one of the contracting parties, or of some combination of which he is a member or which dictates his policy." ${ }^{\prime 1}$

In a case of great interest, The Great Atlantic and Pacific Tea Co. v. Cream of Wheat Co., ${ }^{62}$ Judge Hough pointed out that if the defendant's refusal to do business with the plaintiff "affected a necessity of life, or even a staple article of trade, the matter might be serious," but as defendant handled less than one per cent of the total product in question, it could not in any sense be said to have a monopoly. ${ }^{63}$

It would be interesting to have a patent or copyright case now arise where there was an attempt by license notice to restrict price on an article which could practically be duplicated, without

${ }^{69}$ Argument of counsel, Standard Sanitary Mfg. Co. case (1912) 226 U. S. 20, 3I, 32, 47.

${ }^{60}$ Straus v. American Publisher's Association (1913) 23 U. S. 222, 236. 61 (Igr3) 76 Wash. 649, 660.

62 (IgI5) 224 Fed. 566; Rome G. Brown, The Right to Refuse to Sell, 25 YaLe LaW Journat, 194.

${ }^{63}$ The writer has been greatly aided by the briefs loaned him by the counsel in that case. 
infringement, by purchase in the open market, or in other words, where the patentee or copyright owner could not be said to have anything partaking of the nature of a monopoly. Whether the Supreme Court would permit price-fixing where there was no monopoly seems doubtful. The tendency of their decisions is the other way. The American Publisher's case gave some attention to the monopolistic feature of the defendant's agreement but the Bauer case had nothing to say on that score except to remark that while it was doubtless within the power of Congress to confer on a patentee the right to fix the price of an article of general use, it had not yet done so. ${ }^{64}$

The question remains as one of the interesting speculations suggested by our subject. We must wait for further decisions before it can be said that the policy of the Federal Courts toward price-fixing where there is no monopoly is definitely determined.

Justice Holmes, in a dissenting opinion, in the Dr. Miles Medical Co. case, ${ }^{65}$ written in his usual clear and lucid style, discusses price-fixing in its broader aspects. He believes that the value to the public of competition in production or distribution as fixing a fair price is greatly exaggerated. What really fixes prices is the competition of conflicting desires. None of us having enough of all the things that we want, we must choose. As soon as the price of something we want goes up beyond the point at which we are willing to give up other things to have it, we cease to buy it and buy something else. Hence fair price should be determined by what he terms the equilibrium of social desires, and not by artificial attempts to stimulate competition.

This, of course, is Justice Lurton's argument in the Dick case with reference to a patented article, and, it is submitted, a view that has logic and common sense with it.

Justice Holmes specifically excepts from his reasoning things which we cannot get along without-"there may be necessaries that sooner or later must be dealt with like short rations in a shipwreck, but they are not Dr. Miles's medicines."

${ }^{64}$ Judge Hough has this footnote to the Cream of Wheat case (I915) 224 Fed. 566, 575: "It is an interesting speculation, whether national price regulation, embracing compulsory sales, could not be reached by a system of federal licenses as a prerequisite for interstate business. Semble that submission to such prospective regulatory orders might be exacted as the price of license."

65 (I9II) 220 U. S. 373, 409. 
It may be that the court will eventually take the viewpoint that where the monopoly of the patent or the copyright can be maintained without the creation of a general monopoly in a necessary of life, there will be no objection in public policy to permitting price-fixing by the patentee or copyright owner. It must be admitted, however, that our "present enthusiasm for regulating the prices to be charged by other people," as Justice Holmes terms it, is against this view. It should be a question of the balance of convenience-"no more restraint than necessary to afford a fair protection to the business of the complainant and not so large as to interfere with the interests of the public,"6s or, as similarly laid down in the Dr. Miles case:

"Public welfare is first considered and if it be not involved, and the restraint upon one party is not greater than protection to the other party requires, the contract may be sustained." 67

There seems a tendency to define the word, "monopoly,: too narrowly. Because a certain concern has a monopoly in all of "Sanatogen" or "Peruna" or "Cream of Wheat," it does not necessarily follow that the public interest will suffer because of price restrictions. These may be monopolies in mere names and not in commodities. Of course, that was literally true in the Cream of Wheat case, where the name simply designated a very small percentage of purified middlings, but it is practically true in the case of these proprietary medicines as well, for I venture to assert that no single one of them is so unique and indispensable that it would be greatly detrimental to the public if the makers were permitted to fix their own prices. A price too high would permit users to turn to many substitutes fully as good.

There is a consideration involved in cases like the American Publisher's case which should be kept in mind, and that is whether the injunction sought against patent and copyright owners may not, as a practical matter, compel the owner to sell his goods to one with whom he prefers not to have business dealings. "It is not unlawful for a person to refuse to deal with others as his judgment, or fancy, may impel him." ${ }^{38}$ The Cream of Wheat

\footnotetext{
os Park \& Sons Co. v. Hartman (1907) I53 Fed. 24, 43.

${ }^{\circ 7}$ (IgIr) 2200 U. S. $373,406$.

as Gray, J., dissenting in Straks v. American Publisher's Association (1914) 177 N. Y. $473,490$.
} 
case shows this plainly enough, but when he agrees with others that he will refuse to sell except under certain conditions, he may have entered an unlawful combination, as is brought out by the American Publisher's case.

The vital difference is the fact of a combination and it is, of course, a distinction very frequently made and well grounded. The court, in dissolving the book publishers' and book-sellers' combination, did not order any single defendant to do business with the plaintiffs. Suppose, however, there had been one large defendant corporation controlling all this trade and no combination to attack, what would have been the substance of the court's decree? In the light of the Standard Oil case, ${ }^{69}$ it is possible to say that the court lays more stress on the fact of monopoly than on the detail whether the monopoly is created by the acts of one owner or of a combination of owners. Nlo case has yet told us what would be the treatment accorded the large corporation with a patent or copyright monopoly of something akin to a necessary of life. While it is unlikely, it is not at all impossible for such a situation to arise, and it is certain that we may look for more interesting decisions which will discuss more fully this problem of the relation of statutory monopolies and anti-monopoly legislation.

NEW YoRk BAR.

F. Granville Munson.

${ }^{69}$ (IgII) $22 \mathrm{I}$ U. S. I. 